\title{
Jurist-Diction
}

Volume 3 No. 5, September 2020

\section{Batasan, Wewenang dan Keterlibatan KPPU Dalam Kasus Persekongkolan Tender Menurut Hukum Persaingan Usaha}

\author{
Alya Anindita Maheswari \\ alyaaninditamaheswari@gmail.com \\ Universitas Airlangga
}

How to cite:

Alya Anindita Maheswari,

'Batasan, Wewenang Dan

Keterlibatan Kppu Dalam

Kasus Persekongkolan Tender

Menurut Hukum Persaingan

Usaha' (2020) Vol. 3 No. 5

Jurist-Diction.

Histori artikel:

Submit 15 Juli 2020;

Diterima 14 Agustus 2020;

Diterbitkan 1 September 2020.

DOI:

10.20473/jd.v3i5.21967

\begin{abstract}
Abstrak
Dewasa ini perekonomian dunia semakin maju, banyak negara berkembang yang hingga saat ini berusaha meningkatkan taraf perkenomian negara, tak terkecuali Indonesia. Semakin maju perekonomian, semakin banyak pula peluang dan pesaing dalam meluaskan suatu usaha. Di Indonesia permasalahan yang paling mendasar dalam hal perekonomian saat ini salah satunya adalah mengenai persekongkolan tender. KPPU sebagai lembaga pengawas yang mengawasi arus persaingan usaha di Indonesia, berwenang untuk memberikan sanksi dan tindakan administratif kepada pelaku usaha yang terbukti melakukan persaingan usaha tidak sehat, salah satunya adalah persekongkolan. Persekongkolan ini termasuk dalam klasifikasi tindakan yang dilarang oleh Undang-Undang Nomor 5 tahun 1999 karena dapat merugikan keuangan negara. Undang-Undang Nomor 5 tahun 1999 mengatur tindakan persekongkolan dapat dijatuhi sanksi administratif dan sanksi pidana. Peraturan dalam Undang-Undang Nomor 5 tahun 1999 adalah wewenang khusus yang dimiliki oleh KPPU, termasuk mengenai sanksi pidana. Tujuan penulisan ini adalah untuk mengkaji sejauh mana batasan dan wewenang KPPU dalam penerapan sanksi pidana terhadap kasus persekongkolan tender yang berimplikasi tindak pidana.

Kata Kunci: Persaingan Usaha Tidak Sehat; Persekongkolan Tender; Sanksi Pidana; Keterlibatan KPPU.
\end{abstract}

\section{Pendahuluan}

Globalisasi telah menjadi pendorong utama bagi munculnya integrasi ekonomi dunia. Saat ini globalisasi telah membuka peluang yang lebih luas bagi negara untuk meningkatkan volume perdagangan dengan melakukan ekspansi usaha ke pasar internasional, terutama bagi negara berkembang. Melalui globalisasi dapat dilakukan peningkatan investasi, baik langsung maupun tidak langsung yang akhirnya mendorong pertumbuhan ekonomi dan lapangan kerja. ${ }^{1}$ Indonesia

1 Andy Fahmi Lubis, Anna Maria Tri Anggraini, Kurnia Toha, Budi L. Kagramanto, Hukum Persaingan Usaha Antara Teks dan Konteks (Komisi Pengawas Persaingan Usaha 2009).[ix]. 
merupakan salah satu negara berkembang yang hingga saat ini meningkatkan taraf perekonomian negara. Terbukanya peluang tersebut tak hanya memberikan angin segar bagi pelaku usaha namun juga memberikan tantangan bagi pelaku usaha, salah satunya adalah semakin bervariasinya produk-produk hasil produksi negara luar yang dijual di negara dalam negeri (domestik). Tantangan tersebut tentunya dapat menjadi sebuah persaingan antar para pelaku usaha. Persaingan dapat terjadi jika terdapat beberapa pelaku usaha yang memasarkan suatu produk yang sama dilingkungan yang sama pula. Semakin ketatnya persaingan tersebut, maka kemungkinan untuk terjadinya persaingan usaha tidak sehat tentu akan semakin besar. Persaingan usaha tidak sehat tentunya dapat memberikan dampak negatif tidak hanya bagi pelaku usaha dan konsumen, tetapi juga bagi perekonomian nasional. ${ }^{2}$ Demi menghindari terjadinya persaingan usaha yang tidak sehat diperlukan suatu aturan hukum sebagai pedoman dan payung hukum bagi para pelaku usaha dalam menjalankan usahanya.

Menurut L. Budi Kagramanto, secara yuridis, persaingan usaha identik dengan persaingan ekonomi yang berstandar pada pasar, yaitu ketika pelaku usaha baik perusahaan maupun penjual dapat leluasa berusaha mendapatkan konsumen guna mencapai tujuan yang diinginkannya. ${ }^{3} \mathrm{Hal}$ ini adalah cerminan bahwa untuk mencapai tujuan yang diingikan oleh pelaku usaha, diperlukan persaingan usaha yang sehat.

Setiap negara memakai istilah yang berbeda dalam menyebut hukum persaingan usaha. Salah satunya adalah Amerika Serikat yang menyebut sebagai antitrust law. Indonesia memakai istilah hukum persaingan usaha karena dipandang paling tepat apabila dilihat dari substansi Undang-Undang Nomor 5 tahun 1999 tentang Larangan Praktek Monopoli dan Persaingan Usaha Tidak Sehat sebagai peraturan pokok hukum persaingan usaha di Indonesia.

Hadirnya Undang-Undang Nomor 5 tahun 1999 adalah berawal dari inisiatif Dewan Perwakilan Rakyat (DPR) untuk menyusun Rancangan Undang-Undang

2 Hermansyah, Pokok-Pokok Hukum Persaingan Usaha di Indonesia (Kencana Prenada Media Group 2008). [10].

3 L. Budi Kagramanto, Mengenal Hukum Persaingan Usaha (Laras 2010).[57]. 
Larangan Praktek Monopoli dan Persaingan Usaha Tidak Sehat. RUU ini kemudian disetujui dalam Sidang Paripurna DPR tanggal 18 Februari 1999 dan diundangkan pada tanggal 5 Maret 1999 dalam Lembaran Negara Republik Indonesia Tahun 1999. ${ }^{4}$

Secara umum, tujuan Undang-Undang Nomor 5 Tahun 1999 adalah untuk menjaga iklim persaingan antar pelaku usaha dan menjadikan persaingan antar pelaku usaha menjadi sehat, serta bertujuan menghindari terjadinya eksploitasi terhadap konsumen oleh pelaku usaha tertentu serta mendukung sistem ekonomi pasar yang dianut oleh suatu negara. Secara yuridis, tujuan persaingan usaha diatur dalam Pasal 3 Undang-Undang Nomor 5 tahun 1999, berdasarkan pasal tersebut dapat diketahui bahwa tujuan persaingan usaha yang diatur dalam Undang-Undang Nomor 5 tahun 1999 tidak hanya menitikberatkan visinya pada aspek kompetisi (bersaing), tetapi juga membawa visi sebagai suatu behaviour of conduct dalam tatanan dunia usaha, termasuk melindungi masyarakat konsumen di tanah air. ${ }^{5}$

Demi berlangsungnya Undang-Undang Nomor 5 tahun 1999 maka diperlukan sebuah lembaga untuk mengawasi para pelaku usaha dalam menjalakan kegiatan usahanya karena persaingan usaha yang sehat menjadi salah satu kunci dari suksesnya sistem ekonomi pasar yang wajar. Hal ini dapat diwujudkan dengan adanya penegakan hukum persaingan usaha dan kebijakan mengenai persaingan usaha yang kondusif terhadap perkembangan ekonomi. Kedua hal ini harus bersinergi agar tercipta iklim persaingan usaha yang sehat dalam ekonomi kita, ${ }^{6}$ maka dari itu pemerintah melalui Keputusan Presiden Nomor 75 tahun 1999 membentuk lembaga Komisi Pengawas Persaingan Usaha (KPPU). Peraturan mengenai status, kewenangan dan tugas KPPU telah diatur dalam bab IV Pasal 30 sampai Pasal 37 Undang-Undang Nomor 5 tahun 1999.

Berstatus sebagai lembaga pengawas, maka KPPU merupakan lembaga independen yang terlepas dari pengaruh dan kekuasaan pemerintah dan pihak

\footnotetext{
4 Andy Fahmi Lubis et al., Op.Cit.[31].

5 L. Budi Kagramanto, Larangan Persekongkolan Tender (Perspektif Hukum Persaingan Usaha), (Srikandi 2007).[13].

6 Kerti Renti Maharaini, "Hukum Acara Persaingan Usaha", <https://sekartrisakti.wordpress.com/2011/05/14/hukum-acara-persaingan-usaha/> accessed 19 Agustus 2019.
} 
lain. ${ }^{7}$ Tugas utama KPPU adalah melakukan penegakan hukum persaingan usaha sebagaimana diatur dalam Undang-Undang Nomor 5 tahun 1999. Seperti yang diketahui bahwa KPPU bukanlah lembaga peradilan khusus persaingan usaha sehingga KPPU tidak dapat menjatuhkan hukuman selain sanksi administratif.

Pasal36Undang-Undang Nomor 5 tahun 1999mengaturmengenaikewenangan yang dimiliki KPPU salah satunya adalah berwenang untuk melakukan penelitian, penyelidikan, memutuskan apakah pelaku usaha telah melanggar Undang-Undang Nomor 5 tahun 1999, serta berwenang menjatuhkan sanksi administratif. Disamping itu, Undang-Undang Nomor 5 tahun 1999 juga mengatur mengenai sanksi pidana namun dalam undang-undang tersebut tidak disebutkan bahkan tidak dijelaskan mengenai wewenang KPPU dalam menjatuhkan sanksi pidana. Sepanjang putusan yang telah dibuat oleh KPPU mengenai kasus yang mereka tangani, hukuman yang dijatuhkan kepada pelaku usaha yang terbukti melanggar ketentuan UndangUndang Nomor 5 tahun 1999 hanya sebatas pada pemberian sanksi administratif yang sesungguhnya pelanggaran tersebut telah memenuhi unsur dalam Pasal 48 Undang-Undang Nomor 5 tahun 1999.

Salah satu permasalahan mendasar terkait persaingan usaha di Indonesia adalah mengenai proses pengadaan barang/jasa pemerintah. Dalam proses pengadaan barang dan jasa pemerintah, beberapa kalangan menilai, masih banyak dijumpai praktek persekongkolan untuk menentukan pemenang dalam sebuah tender ${ }^{8}$. Hal ini jelas bertentangan prinsip serta mekanisme yang telah diatur dalam Perpres Nomor 54 tahun 2010 tentang Pengadaan Barang/Jasa Pemerintah serta Undang-Undang Nomor 5 tahun 1999.

Pada hakekatnya, persekongkolan tender merupakan suatu perbuatan yang dilakukan, baik oleh pihak penyedia barang/jasa maupun pengguna barang/jasa untuk mengatur dan menentukan pemenang tender. Berdasarkan jenisnya persekongkolan

7 T.R. Silalahi, 'Kompetensi Komisi Pengawas Persaingan Usaha (KPPU) Dalam Menanggulangi Praktek Monopoli Dan Persaingan Usaha Tidak Sehat' (Universitas Airlangga 2002).

8 Yakub Adi Krisanto, 'Terobosan Hukum Keputusan KPPU dalam Mengembangkan Penafsiran Hukum Persekongkolan Tender' (2008) 3 Volume 27 Jurnal Hukum Bisnis.[63]. 
tender dapat dibedakan menjadi 3 (tiga) jenis, yaitu: Persekongkolan secara Horizontal, Persekongkolan secara Vertikal, dan Gabungan Persekongkolan secara Horizontal dan Vertikal.

Tender yang bertujuan memperoleh pemenang, paling tidak harus terdiri dari 2 (dua) atau lebih pelaku usaha agar ide dasar pelaksanaan tender berupa perolehan harga terendah dengan kualitas terbaik dapat tercapai. ${ }^{9}$ Disisi lain, persekongkolan tender juga dapat menimbulkan tindakan kolusif yang bertujuan untuk meniadakan persaingan dan menaikan harga. Undang-Undang Nomor 5 tahun 1999 memberikan 2 (dua) jenis sanksi untuk pelanggaran mengenai persekongkolan tender, yaitu sanksi administratif dan sanksi pidana.

Pakar hukum Universitas Islam Indonesia Yogyakarta Mudzakkir menuturkan bahwa UU Anti Monopoli (Undang-Undang Nomor 5 tahun 1999) seolah memberikan peran yang begitu besar kepada KPPU, ${ }^{10}$ penuturan Mudzakkir tersebut berkaitan dengan mekanisme penegakkan hukum dan pemberian sanksi dalam Undang-Undang Nomor 5 tahun 1999. Sejauh ini, Undang-Undang Nomor 5 tahun 1999 hanya mengatur bahwa KPPU dapat meminta bantuan penyidik apabila terlapor, saksi ahli yang telah dipanggil secara patut oleh KPPU mengabaikan panggilan tersebut. Disamping itu juga terdapat Peraturan Komisi Pengawas Persaingan Usaha Nomor 1 tahun 2019 tentang Tata Cara Penanganan Perkara di KPPU, namun dalam Perkom tersebut tidak pula dijelaskan mengenai mekanisme penerapan sanksi pidana dalam Undang-Undang Nomor 5 tahun 1999.

\section{Batasan dan Wewenang KPPU Dalam Menjatuhkan Sanksi Pidana Dalam Kasus Persekongkolan Tender}

Dalam sistem ketatanegaraan Indonesia, KPPU adalah lembaga negara penunjang (State Auxiliary Organ) 16 yang berwenang melakukan penegakan

\footnotetext{
9 Yakub Adi Krisanto, 'Analisis Pasal 22 UU No. 5 Tahun 1999 dan Karekteristik Putusan KPPU tentang Persekongkolan Tender' (2005) 2 Volume 24, Jurnal Hukum Bisnis [45].

10 Sut 'Mempersoalkan Sanksi Pidana dalam Hukum Persaingan Usaha', <https://www.hukumonline.com/berita/baca/hol21865/mempersoalkan-sanksi-pidana-dalam-hukum-persaingan-usaha/> accessed 19 Agustus 2019.
} 
hukum persaingan usaha sebagaimana yang telah tertuang dalam Undang-Undang Nomor 5 tahun 1999. State Auxiliary Organ adalah lembaga negara yang dibentuk diluar Undang-Undang Dasar 1945 yang membantu pelaksanaan tugas lembaga negara mandiri atau yang biasa disebut sebagai lembaga negara utama. State Auxiliary Organ lahir dikarenakan negara memiliki tujuan-tujuan yang ingin dicapai. Demi mencapai tujuan, negara harus memiliki dan menyelenggarakan fungsi-fungsi tertentu. Maka dari itu suatu negara memerlukan alat-alat pelengkap negara yaitu lembaga negara penunjang untuk dapat mencapai fungsi-fungsi tertentu tersebut.17KPPU merupakan lembaga negara penunjang (State Auxiliary Organ) ${ }^{11}$ yang berwenang melakukan penegakan hukum persaingan usaha sebagaimana yang telah tertuang dalam Undang-Undang Nomor 5 tahun 1999.

State Auxiliary Organ adalah lembaga negara yang dibentuk diluar UndangUndang Dasar 1945 yang membantu pelaksanaan tugas lembaga negara mandiri atau yang biasa disebut sebagai lembaga negara utama. Kedudukan KPPU sebagai State Auxiliary Organ adalah lembaga independen yang dibentuk berdasarkan undang-undang, ${ }^{12}$ dan merupakan lembaga independen yang terlepas dari segala bentuk pengaruh kekuasan Pemerintah dan pihak lain.

KPPU dibentuk dengan tujuan dapat menjamin iklim usaha yang kondusif, yakni adanya persaingan usaha yang sehat, serta agar dapat terciptanya efisiensi dan efektifitas suatu kegiatan usaha. ${ }^{13}$ Pada praktiknya, lembaga negara di Indonesia ada yang dibentuk berdasarkan konstitusi, undang-undang, dan berdasarkan peraturan presiden. Masing-masing kedudukannya tentu bergantung pada kedudukan pengaturannya menurut peraturan perundang-undangan yang berlaku. Maka dari itu lembaga negara yang dibentuk berdasarkan undang-undang disebut organ undangundang, sedangkan yang hanya dibentuk berdasarkan peraturan presiden tentu

${ }^{11}$ L. Budi Kagramanto, 'Implementasi UU No 5 Tahun 1999 oleh KPPU' (2007) Jurnal Ilmu Hukum Yustisia.[2].

12 ibid.

13 Andy Fahmi Lubis et al, Op.Cit.[330]. 
kedudukan dan derajat perlakuan hukumnya lebih rendah. ${ }^{14}$ Biasanya lembagalembaga penunjang dibentuk pada sektor cabang kekuasaan seperti eksekutif dan yudikatif yang fungsinya dapat berupa sebagai lembaga pengawas terhadap lembaga negara utama yang berada di sektor yang sama atau mengambil alih beberapa kewenangan lembaga negara utama di sektor yang sama. ${ }^{15}$

Dalam menjalankan tugasnya, KPPU bertanggungjawab kepada Presiden. Hal ini merupakan suatu ketentuan yang wajar karena KPPU bertugas untuk melaksanakan sebagian dari tugas pemerintah. Dalam hal ini, pemerintah dengan kekuasaan tertinggi ada dibawah Presiden. Meskipun bertanggungjawab kepada Presiden, independensi KPPU tidak terganggu karena adanya keterlibatan DPR untuk turut serta dalam menentukan dan mengontrol pengangkatan dan pemberhentian anggota KPPU. ${ }^{16}$ KPPU dibentuk dengan harapan dapat melakukan pengawasan terhadap pelaku usaha dalam menjalankan kegiatan usahanya agar tetap pada koridornya (agar tidak melakukan perbuatan yang dilarang, mengadakan perjanjian yang dilarang, atau adanya penyalahgunaan posisi dominan yang dilarang yang dapat mengakibatkan terjadinya praktik monopoli dan/atau persaingan usaha tidak sehat sehingga dapat menimbulkan iklim persaingan usaha yang kompetitif dan kondusif). ${ }^{17} \mathrm{KPPU}$ dalam melaksanakan fungsinya sebagai lembaga pengawas pelaksanaan Undang-Undang Nomor 5 tahun 1999 memiliki tugas dan wewenang untuk melaksanakan tugasnya yang diatur di dalam Pasal 35 dan Pasal 36 UndangUndang Nomor 5 tahun 1999. Pasal 35 huruf f, mengatur bahwa KPPU berwenang untuk menyusun pedoman ataupun segala bentuk publikasi yang berkaitan dengan Undang-Undang Nomor 5 tahun 1999. Berdasarkan hal tersebut, KPPU berwewenang untuk membuat hukum acara tersendiri mengenai proses penanganan perkara pelanggaran terhadap Undang-Undang Nomor 5 tahun 1999, maka

\footnotetext{
${ }^{14}$ Patrialis Akbar, Lembaga-lembaga Negara Menurut UUD NRI Tahun 1945 (Sinar Grafika 2002).[10].

15 ibid. [312-313].

16 ibid.[331].

${ }_{17}$ Rachmadi Usman, Hukum Persaingan Usaha di Indonesia (PT. Gramedia Pustaka Utama 2010).[355-356].
} 
KPPU mengeluarkan beberapa produk hukum yaitu Keputusan KPPU Nomor 5/ Kep/IX/2000 tentang Tata Cara Penyampaian Laporan dan Penanganan Dugaan Pelanggaran terhadap Undang-Undang Nomor 5 tahun 1999, Peraturan Komisi Pengawas Persaingan Usaha Nomor 1 tahun 2006 tentang Tata Cara Penanganan Perkara di KPPU yang kemudian dicabut dan diperbaharui dengan Peraturan Komisi Pengawas Persaingan Usaha Nomor 1 tahun 2019 tentang Tata Cara Penanganan Perkara Praktik Monopoli dan Persaingan Usaha Tidak Sehat. Wewenang yang diatur dalam Pasal 36 Undang-Undang Nomor 5 tahun 1999 merupakan suatu koridor bagi KPPU dalam menjalankan tugas-tugasnya, sehingga KPPU tidak dapat dengan semaunya dalam menjalankan tugasnya.

Selain memiliki tugas yang harus dilaksanakan, KPPU memiliki wewenangwewenang yang diatur dalam Pasal 36 Undang-Undang Nomor 5 tahun 1999, yaitu:

a. menerima laporan dari masyarakat dan atau dari pelaku usaha tentang dugaan terjadinya praktek monopoli dan atau persaingan usaha tidak sehat;

b. melakukan penelitian tentang dugaan adanya kegiatan usaha dan atau tindakan pelaku usaha yang dapat mengakibatkan terjadinya praktek monopi dan atau persaingan usaha tidak sehat;

c. melakukan penyelidikan dan atau pemeriksaan terhadap kasus dugaan praktek monopoli dan atau persaingan usaha tidak sehat yang dilaporkan oleh masyarakat atau oleh pelaku usaha atau yang ditemukan oleh Komisi sebagai hasil penelitiannya;

d. menyimpulkan hasil penyelidikan dan atau pemeriksaan tentang ada atau tidak adanya praktek monopoli dan atau persaingan usaha tidak sehat;

e. memanggil pelaku usaha yang diduga telah melakukan pelanggaran terhadap ketentuan undang-undang ini;

f. memanggil dan menghadirkan saksi, saksi ahli, dan setiap orang yang dianggap mengetahui pelanggaran terhadap ketentuan undang-undang ini;

g. meminta bantuan penyidik untuk menghadirkan pelaku usaha, saksi, saksi ahli, atau setiap orang sebagaimana dimaksud huruf e dan huruf f, yang tidak bersedia memenuhi panggilan Komisi;

h. meminta keterangan dari instansi Pemerintah dalam kaitannya dengan penyelidikan dan atau pemeriksaan terhadap pelaku usaha yang melanggar ketentuan undang-undang ini;

i. mendapatkan, meneliti, dan atau menilai surat, dokumen, atau alat bukti lain guna penyelidikan dan atau pemeriksaan;

j. memutuskan dan menetapkan ada atau tidak adanya kerugian di pihak pelaku usaha lain atau masyarakat;

k. memberitahukan putusan Komisi kepada pelaku usaha yang diduga melakukan praktek monopoli dan atau persaingan usaha tidak sehat; 
I. menjatuhkan sanksi berupa tindakan administratif kepada pelaku usaha yang melanggar ketentuan undang-undang ini.

Peraturan Komisi Pengawas Persaingan Usaha Nomor 1 tahun 2019 tentang Tata Cara Penanganan Perkara Praktik Monopoli dan Persaingan Usaha Tidak Sehat merupakan hukum acara dan pedoman bagi KPPU dalam melaksanakan wewenangnya dalam Pasal 36 Undang-Undang Nomor 5 tahun 1999. Dari wewenang-wewenang tersebut, terlihat bahwa KPPU tidak dapat secara semaunya dalam menjalankan wewenangnya agar tidak melampaui koridor status kelembagaannya.

Pertama, kewenangan penelitian dan penyelidikan pada Pasal 36 huruf a dan b menyatakan bahwa KPPU dapat melakukan penelitian dan penyelidikan terkait kasus dugaan praktik monopoli. Apabila dalam proses penelitian dan penyelidikan tersebut investigator merasa diperlukan bukti lain, KPPU tidak dapat melakukan penggeledahan terhadap pelaku usaha terkait karena KPPU tidak memiliki wewenang tersebut.

Kedua, pada Pasal 36 huruf f, KPPU berwenang untuk memanggil pelaku usaha ataupun saksi terkait. Apabila pelaku usaha ataupun saksi terkait KPPU tidak memenuhi panggilan penyelidikan tersebut, KPPU tidak dapat memaksa pelaku usaha dan saksi untuk memenuhinya karena KPPU tidak memiliki wewenang untuk memaksa.

Ketiga, pada Pasal 36 huruf 1 KPPU berwenang menjatuhkan sanksi berupa tindakan administratif apabila pelaku usaha terbukti telah melanggar ketentuan Undang-Undang Nomor 5 tahun 1999. Tindakan administratif diatur lebih lanjut pada Pasal 47 ayat (2) Undang-Undang Nomor 5 tahun 1999, namun dalam undang-undang ini juga diatur mengenai ketentuan sanksi pidana pada Pasal 48. Hal ini seringkali menimbulkan pro dan kontra karena pengaturan sanksi pidana dalam Pasal 48 hanya sebatas mengenai bentuk sanksi pidana yang dijatuhkan, tetapi dalam undang-undang tersebut tidak diatur dan tidak dijelaskan lebih lanjut mengenai siapa yang dapat menjatuhkan sanksi pidana tersebut. Dari kewenangankewenangan tersebut terlihat jelas bahwa wewenang Majelis Komisi dalam 
menjatuhkan sanksi sangat terbatas, yaitu sanksi yang dapat dijatuhkan hanyalah sebatas sanksi administratif. Sanksi administratif tersebut terbatas pada apa yang telah diatur dalam Pasal 47 ayat (2) Undang-Undang Nomor 5 tahun 1999, sehingga Majelis Komisi tidak dapat menjatuhkan sanksi lain selain sanksi yang telah diatur dalam pasal tersebut.

Sebagai State Auxiliary Organ, KPPU diberikan wewenang untuk melakukan penyelidikan. Wewenang ini tertuang dalam Pasal 36 huruf c, d, h, dan huruf i serta Psal 41 ayat (1) dan (2) Undang-Undang Nomor 5 tahun 1999 memuat mengenai frasa "penyelidikan". Frasa "penyelidikan" dalam undang-undang persaingan usaha ini beberapa kali dijadikan sebagai senjata bagi pelaku usaha yang telah terbukti secara sah dan meyakinkan telah melanggar ketentuan Undang-Undang Nomor 5 tahun 1999, dalam mengajukan keberatan melalui Pengadilan Negeri. Hal ini terjadi dikarenakan frasa "penyelidikan" tersebut acapkali dianggap memiliki makna yang sama dengan frasa "penyelidikan" dalam perkara pidana. Apabila dipahami lebih dalam, frasa "penyelidikan" dalam Undang-Undang Nomor 5 tahun 1999 memiliki makna yang berbeda dengan frasa "penyelidikan" dalam perkara pidana. Berdasarkan putusan Mahkamah Konstitusi Nomor 85/PUU-XIV/2016, frasa “penyelidikan" dalam Undang-Undang Nomor 5 tahun 1999 adalah pengumpulan alat bukti sebagai bahan pemeriksaan. Putusan Mahkamah Konstitusi tersebut sesuai dengan karakteristik KPPU sebagai State Auxiliary Organ, sehingga KPPU tidak melakukan penyelidikan layaknya penegak hukum di ranah hukum pidana, sedangkan frasa "penyelidikan" dalam perkara pidana tertuang dalam Pasal 1 angka 5 Kitab Undang-Undang Hukum Acara Pidana, yang berbunyi: "Penyelidikan adalah serangkaian tindakan penyelidik untuk mencari dan menemukan suatu peristiwa yang diduga sebagai tindak pidana guna menentukan dapat atau tidaknya dilakukan penyidikan menurut cara yang diatur dalam undang-undang ini”. Jika dicermati lebih dalam, makna frasa "penyelidikan" dalam perkara pidana adalah suatu tindakan untuk menentukan terjadinya suatu peristiwa tindak pidana. Maka dari itu, frasa "penyelidikan" dalam Undang-Undang Nomor 5 tahun 1999 memiliki makna yang berbeda dengan frasa "penyelidikan" dalam Undang-Undang Nomor 
8 tahun 1981 tentang Hukum Acara Pidana. Penyelidikan dalam Undang-Undang Nomor 5 tahun 1999 dilakukan guna menentukan apakah telah terjadi pelanggaran terhadap Undang-Undang Nomor 5 tahun 1999.

Penyelidikan dalam Undang-Undang Nomor 5 tahun 1999 dilakukan guna menentukan apakah telah terjadi pelanggaran terhadap Undang-Undang Nomor 5 tahun 1999. Wewenang penyelidikan dalam undang-undang tersebut memiliki 4 objek penyelidikan sebagaimana yang telah diatur dalam Peraturan Komisi Pengawas Persaingan Usaha Nomor 1 tahun 2010 tentang Tata Cara Penanganan Perkara (Perkom Nomor 1 tahun 2010), yaitu:

1. Hasil klarifikasi atau penelitian atas laporan dugaan pelanggaran;

2. Laporan hasil kajian industri yang dilakukan oleh komisi;

3. Hasil penelitian unit kerja KPPU bidang monitoring; dan

4. Hasil pengawasan terhadap pelaku usaha.

Selama menjalankan wewenang penyelidikan, dalam praktik dilapangan tidak sedikit KPPU mengalami berbagai macam kendala, salah satunya adalah dengan adanya sifat kerahasiaan perusahaan, hal tersebut menyebabkan KPPU tidak dapat mendapatkan data perusahaan yang diperlukan. Apabila KPPU mengalami kendala tersebut, KPPU dapat meminta bantuan penyidik karena KPPU tidak dapat melakukan penggeledahan maupun melakukan tindakan (upaya) paksa terhadap perusahaan yang terkait dengan kasus dugaan pelanggaran terhadap UndangUndang Nomor 5 tahun 1999.

\section{Keterlibatan KPPU Dalam Kasus Persekongkolan Tender}

Penanganan Perkara oleh KPPU baik dalam perkara persekongkolan tender maupun perkara lain yang melanggar undang-undang ini adalah berdasarkan laporan pelapor, laporan pelapor dengan ganti rugi, dan inisiatif Komisi. Apabila dalam laporan pelapor berupa pengaduan ke KPPU dirasa diduga adanya indikasi telah terjadi tindakan pelaku usaha yang melanggar ketentuan Pasal 47, maka inisiatif Komisi untuk mengetahui telah terjadi atau tidaknya suatu tindakan persekongkolan dalam tender adalah dengan mencari berbagai indikasi persekongkolan yang sering terjadi pada proses pelaksanaan tender, selain itu bentuk dan perilaku persekongkolan 
ataupun ada tidaknya persekongkolan harus dibuktikan dengan dilakukannya pemeriksaan oleh Majelis KPPU atau Tim Pemeriksa. Berikut merupakan indikasi persekongkolan tender, yaitu: ${ }^{18}$

a. indikasi persekongkolan terjadi pada saat perencanaan;

b. indikasi persekongkolan terjadi pada saat pembentukan panitia;

c. indikasi persekongkolan terjadi pada saat adanya pra-lelang atau prakualifikasi perusahaan;

d. indikasi persekongkolan terjadi pada saat pembuatan persyaratan untuk mengikuti tender atau lelang maupun saat penyusunan dokumen tender atau lelang;

e. indikasi persekongkolan saat pengumuman tender atau lelang berlangsung;

f. indikasi persekongkolan saat pengambilan dokumen tender atau lelang;

g. indikasi persekongkolan saat penentuan Harga Perkiraan Sendiri (HPS) atau harga dasar lelang;

h. indikasi persekongkolan terjadi saat penjelasan tender atau open house lelang;

i. indikasi persekongkolan saat penyerahan dan pembukaan dokumen atau kotak penawaran tender/lelang;

j. indikasi persekongkolan terjadi pada saat evaluasi dan penetapan pemenang tender atau lelang;

k. indikasi persekongkolan pada saat pengumuman calon pemenang;

l. indikasi persekongkolan saat pengajuan sanggahan;

m. indikasi persekongkolan pada saat penunjukan pemenang tender atau lelang dan dalam penandatanganan kontrak;

n. indikasi persekongkolan pada saat pelaksanaan dan evaluasi pelaksanaan.

Berdasarkan indikasi-indikasi tersebut serta pengertian pada Pasal 22 undangundang ini, maka KPPU dalam membuktikan tindakan persekongkolan tender harus mencari alat bukti untuk memenuhi unsur-unsur persekongkolan tender. Apabila KPPU dapat memastikan bahwa telah terjadi persekongkolan tender berdasarkan indikasi-indikasi dan alat bukti yang ada, maka berdasarkan undang-undang ini, tindakan persekongkolan tender dapat dijatuhi sanksi adminsitratif dalam Pasal 47 dan sanksi pidana dalam Pasal 48. Sanksi administratif dalam Pasal 47 undangundang ini berupa:

a. perintah kepada pelaku usaha untuk menghentikan kegaitan yang terbukti menimbulkan praktek monopoli dan atau yang menyebabkan persaingan usaha

\footnotetext{
2010).[5].

${ }^{18} \mathrm{KPPU}$, Pedoman Pasal 22 tentang Larangan Persekongkolan dalam Tender (Jakarta
} 
yang tidak sehat atau merugikan masyarakat;

b. penetapan pembayaran ganti rugi;

c. pengenaan dendea serendah-rendahnya Rp. 1.000.000.000,- dan setinggitingginya Rp. 25.000.000.000,--

\section{Keterlibatan KPPU dalam Penerapan Sanksi Pidana}

Berdasarkan tugas dan wewenang yang telah diatur dalam undang-undang ini, terhadap pelaku usaha yang telah terbukti melanggar ketentuan undang-undang ini, KPPU dapat menjatuhkan sanksi administratif (baik berupa denda administratif maupun tindakan administratif) serta memberikan rekomendasi kepada instansi lain yang terkait dengan kasus yang sedang mereka tangani. Berdasarkan wewenang tersebut, dapat diketahui bahwa KPPU hanya dapat menjatuhkan sanksi adminstratif, sedangkan terhadap pelaku usaha yang terbukti melanggar ketentuanketentuan tertentu dalam sanksi pidana, KPPU hanya dapat memberikan sebuah rekomendasi serta memberikan laporan (melaporkan pelaku usaha terkait) kepada instansi lain yang terkait (seperti Kepolisian, KPK, Kejaksaan dan lain sebagainya) untuk memeriksa secara terpisah kasus yang sedang KPPU tangani, serta KPPU dapat melimpahkan kasus tersebut kepada Kejaksaan, Kepolisan, ataupun KPK.

KPPU dapat memberikan rekomendasi serta melaporkan pelaku usaha kepada instansi lain terkait ketika tim investigator KPPU telah memeriksa berbagai macam alat bukti yang kemudian ditemukan adanya indikasi persekongkolan tender yang dalam hal ini termasuk pada klasifikasi perbuatan yang dilarang, disamping itu KPPU juga dapat melaporkan kepada instansi lain terkait apabila ditemukan indikasi perbuatan tindak pidana seperti tindak pidana korupsi dalam kasus persaingan usaha yang sedang diperiksa oleh tim investigator. Menurut Birowo yang merupakan Kepala Divisi Biro Hukum KPPU Surabaya, ${ }^{19}$ KPPU pernah melaporkan dan melimpahkan kasus kepada instansi lain, baik itu Kejaksaan, Kepolisian, ataupun KPK terutama dalam kasus persekongkolan tender, salah satunya dalam kasus

19 Wawancara dengan Bapak Birowo Kepala Divisi Biro Hukum KPPU Surabaya, 30 Desember 2019. 
persekongkolan tender E-KTP yang melibatkan Percetakan Negara Republik Indonesia (PNRI) dan PT. Astra Graphia pada tahun 2012.

Saat indikasi korupsi ditemukan oleh tim investigator KPPU yang sedang memeriksa alat bukti kasus tersebut, KPPU dapat melaporkan dan melimpahkan kasus tersebut kepada instansi lain yang lebih berwenang (seperti Kepolisian, KPK, ataupun Kejaksaan). Ketika KPPU melimpahkan perkara tersebut kepada instansi lain yang lebih berwenang maka pemeriksaan perkara tersebut sepenuhnya beralih pada instansi lain yang lebih berwenang.

\section{Kesimpulan}

Wewenang dan keterlibatan KPPU dalam menjatuhkan sanksi kepada pelaku usaha yang terbukti secara sah melakukan tindakan persekongkolan tender berdasarkan Undang-Undang Nomor 5 tahun 1999 hanya sebatas pada pemberian sanksi administratif karena KPPU bukanlah suatu lembaga peradilan melainkan sebagai lembaga negara penunjang (State Auxiliary Organ) yang bertugas untuk mengawasi arus persaingan usaha di Indonesia, serta telah diatur dalam Pasal 36 hurufl bahwa KPPU dapat menjatuhkan sanksi berupa tindakan administratifkepada pelaku usaha yang melanggar ketentuan Undang-Undang Nomor 5 tahun 1999. Hal ini berarti bahwa terhadap pelaku yang melanggar ketentuan yang diatur dalam undang-undang ini, dijatuhi sanksi administratif. Sedangkan mengenai keterlibatan KPPU dalam kasus persekongkolan tender, KPPU dapat melaporkan pelaku usaha yang terindikasi atau telah terbukti secara sah dan meyakinkan melakukan persekongkolan tender, kepada instansi lain yang berwenang seperti Kepolisian, KPK dan Kejaksaan. Mengenai sanksi pidana yang diatur dalam Undang-Undang Nomor 5 tahun 1999 merupakan ranah wewenang lembaga peradilan (Pengadilan Negeri dan Mahkamah Agung). Sanksi pidana dalam Undang-Undang Nomor 5 tahun 1999 diberikan kepada pelaku usaha yang melanggar ketentuan tertentu dalam Undang-Undang Nomor 5 tahun 1999 yang dalam kasus ini tindakan persekongkolan tender termasuk didalamnya. 


\section{Daftar Bacaan}

\section{Buku}

Andy Fahmi Lubis, Anna Maria Tri Anggraini, Kurnia Toha, Budi L. Kagramanto, Hukum Persaingan Usaha Antara Teks dan Konteks (Komisi Pengawas Persaingan Usaha 2009).

Hermansyah, Pokok-Pokok Hukum Persaingan Usaha Di Indonesia (Kencana Prenada Media Group 2008).

KPPU, Pedoman Pasal 22 tentang Larangan Persekongkolan dalam Tender, (Komisi Pengawas Persaingan Usaha 2010).

L. Budi Kagramanto, Mengenal Hukum Persaingan Usaha (Laras 2010).

L. Budi Kagramanto, Larangan Persekongkolan Tender (Perspektif Hukum Persaingan Usaha) (Srikandi 2007).

Patrialis Akbar, Lembaga-lembaga Negara Menurut UUD NRI Tahun 1945 (Sinar Grafika 2002).

Rachmadi Usman, Hukum Persaingan Usaha di Indonesia (PT. Gramedia Pustaka Utama 2010).

\section{Jurnal}

L. Budi Kagramanto, 'Implementasi UU No 5 Tahun 1999 oleh KPPU', (2007) Jurnal Ilmu Hukum Yustisia.

Yakub Adi Krisanto, 'Analisis Pasal 22 UU No. 5 Tahun 1999 dan Karekteristik Putusan KPPU tentang Persekongkolan Tender' (2005) 2 Volume 24, Jurnal Hukum Bisnis.

Yakub Adi Krisanto, 'Terobosan Hukum Keputusan KPPU dalam Mengembangkan Penafsiran Hukum Persekongkolan Tender' (2008) 3 Volume 27, Jurnal Hukum Bisnis.

\section{Laman}

Kerti Renti Maharaini, "Hukum Acara Persaingan Usaha", <https://sekartrisakti. wordpress.com/2011/05/14/hukum-acara-persaingan-usaha/> accessed 19 Agustus 2019.

Sut 'Mempersoalkan Sanksi Pidana dalam Hukum Persaingan Usaha', $<$ https:// www.hukumonline.com/berita/baca/hol21865/mempersoalkan-sanksi- 
pidana-dalam-hukum-persaingan-usaha/>, accessed 19 Agustus 2019.

\section{Tesis}

T.R. Silalahi, 'Kompetensi Komisi Pengawas Persaingan Usaha (KPPU) Dalam Menanggulangi Praktek Monopoli Dan Persaingan Usaha Tidak Sehat' (Universitas Airlangga 2002).

\section{Wawancara}

Wawancara dengan Bapak Birowo Kepala Divisi Biro Hukum KPPU Surabaya, 30 Desember 2019. 